Equilibrium: Jurnal Pendidikan

Vol. VIII. Issu 1. Januari-Juni 2020
Prodi Pendidikan Sosiologi

Sosiologi

http://journal.unismuh.ac.id/index.php/equilibrium

\title{
Partisipasi Masyarakat Dalam Program Kota Tanpa Kumuh KOTAKU (Studi Pada Masyarakat Kelurahan Kemboja Kota Tanjung Pinang)
}

\author{
Desrian Efendi ${ }^{1}$, Endri Bagus Prastiyo ${ }^{2}$ \\ ${ }^{1}$ Program Studi Adminsitrasi Publik, Sekolah Tinggi IImu Sosial dan IImu Politik Raja Haji \\ Email: desrianeffendi@stisipolrajahaji.ac.id \\ ${ }^{2}$ Program Studi Sosiologi, Sekolah Tinggi Ilmu Sosial dan Ilmu Politik Raja Haji \\ Email : endribagus@stisipolrajahaji.ac.id
}

\begin{abstract}
This study aims to look at the extent of public participation in the development process Cities Without Slums (KOTAKU) that the major project by the central government. Researchers feel that my city program is still experiencing problems in terms of community participation in every process of development so dikahawatirkan will appear apathy towards development results from the public due to lack of ownership of community development objectives. This research method using Qualitative methods, with the data collection process using the method of observation, interviews and documentation tersetruktur findings were then analyzed using analysis field and Hubermans Miles. The research result can been exposed that do community participation is divided into 3 dimension the dimensions of planning, implementation, and supervision. The fact that the case of the findings of the field there is still a lack of public participation in the development process of my city program in the area where they live. Participation was dilakuakn by some people who are represented in the form of Agency for Self-Reliance Masyarakat (BKM), but participation is not enough, the form of participation that do are more likely to capture the benefits of the program to Kotaku, this of course can have a bad effect to the results of the program which will be abandoned the public because it is considered of no value anymore. If this continues to happen and almost dibairkan mereata same case in different areas of the implementation of the program in the future the results of this program will only be a historical building no longer used because of its sustainability.
\end{abstract}

Keywords: Participation, Society, KOTAKU

Abstrak. Penelitian Ini bertujuan untuk melihat sejauh mana partisipasi masyarakat dalam proses pembangunan Kota Tanpa Kumuh (KOTAKU) yang digalakan oleh pemerintah pusat. Peneliti merasa bahawa program kotaku ini masih mengalami kendala dari segi partisipasi masyarakat dalam setiap proses pembangunannya sehingga dikahawatirkan akan muncul rasa acuh terhadap hasil pembangunan dari masyarakat karena tidak adanya rasa memiliki dari masyarakat sasaran pembangunan. Metode penelitian ini menggunakan metode kualitaif, dengan proses pengumpulan data menggunakan metode observasi, wawancara tersetruktur dan juga dokumentasi, hasil temuan dilapangan selanjutnya dianalisis menggunakan analisi Miles dan Hubermans. Hasil penelitian dapat teruangkap bahwa partispasi yang dapat dilakukan masyarakat terbagi dalam 3 dimnesi yaitu dimensi perencanaan, pelaksanaan, dan pengawasan. Fakta yang terjadi dari hasil temuan lapangan ternyata masih sangat minimnya partisipasi masyarakat dalam proses pembangunan program kotaku di wilayah tempat tinggal mereka. Partisipasi hanya dilakuakn oleh beberapa masyarakat yang terwakilkan dalam bentuk Badan Keswadayaan Masyarakat (BKM) namun partisipasi ini belumlah cukup, bentuk partisipasi yang dilakukan lebih cenderung pengambilan manfaat dari adanya program KOTAKU, hal ini tentu saja dapat memberikan efek buruk bagi hasil program yang nantinya bisa ditinggalkan masyarakat karena dirasa sudah tidak memiliki manfaat lagi. Jika hal ini dibairkan terus terjadi dan hamper mereata kasusnya sama di berbagai wilayah pelaksanaan program maka kedepan hasil dari program ini hanya akan menjadi bangunan sejarah karena tidak dimanfaatkan lagi keberlanjutannya.

Kata Kunci : Partisipasi, Masyarakat, Kota Tanpa Kumuh (KOTAKU) 


\section{PENDAHULUAN}

Kota merupakan pusat berbagai aktivitas ekonomi, perdagangan maupun pendidikan, sehingga memberikan konsekuensi bahwa sebagian besar kegiatan manusia berada di perkotaan. Seiring perkembangan jaman kota menjadi suatu pusat dari berbagai kegiatan yang memiliki bangunan infrastruktur yang lebih maju dibandingkan dengan wilayah desa. kawasan pemukiman yang secara fisik ditunjukkan oleh kumpulan rumah-rumah yang mendominasi tata ruang dan memiliki berbagai fasilitas untuk mendukung kehidupan warganya secara mandiri yang merupakan kompleksitas aspek fisik dan sosial.Keduanya mempunyai sifat yang dinamis sehingga dapat mengalami perubahan dengan cepat yang menimbulkan permasalahan baik bagi warga perkotaan dan pemerintah yang mengelola kota. Bahkan semakin banyaknya pendatang yang menambah permasalahan-permasalahan kota sehingga menjadi makin kompleks. Pertumbuhan penduduk Kepadatan jumlah penduduk yang tinggi di wilayah perkotaan membuat penambahan lokasi permukiman menjadi tidak terkendali dan tidak tertata dengan baik serta akan menciptakan pemukiman yang kumuh.

Dalam Kamus Sosiologi, Soekanto, (1993) Slum's yaitu diartikan sebagai daerah penduduk yang berstatus ekonomi rendah dengan gedung-gedung yang tidak memenuhi syarat kesehatan.Senada dengan Soekanto, Sinulingga (2005) juga mengatakan pemukiman kumuh adalah lingkungan hunian atau tempat tinggal/rumah beserta lingkungannya, yang berfungsi sebagai rumah tinggal dan sebagai sarana pembinaan keluarga, tetapi tidak layak huni ditinjau dari tingkat kepadatan penduduk, sarana dan prasarananya, fasilitas pendidikan, kesehatan serta sarana dan prasarana sosial budaya masyarakat. Pada dasaranya ondisi kumuh sebenarnya masih bisa berubah jika maksimalnya partisipasi semua pihak dalam upaya pengentasan pemukiman kumuh di kawasan perkotaan.

Menurut I Nyoman Sumaryadi (2010) Partisipasi berarti peran serta seseorang atau kelompok masyarakat dalam proses pembangunan baik dalam bentuk pernyataan maupun dalam bentuk kegiatan dengan memberi masukan pikiran, tenaga, waktu, keahlian, modal dan atau materi, serta ikut memanfaatkan dan menikmati hasil -hasil pembangunan. Selanjutnya Theodorson, 2010 dalam Putri, Astuti, \& Rahayu, (2016) Partisipasi merupakan keikutsertaan seseorang didalam kelompok sosial untuk mengambil bagian dari kegiatan masyarakat yang ada, di luar pekerjaannya. Hal senada juga dikemukakan oleh Chandra (2003: 5) yang menjelaskan bahwa partisipasi sebagai pengetahuan dan teknik yang ditujukan sebagai alat penyelesaian masalah-masalah pembangunan, berjalan dan tidaknya, tergantung pada konteks-konteks spesifik yang terkait dengan faktor-faktor struktural, serta institusi-institusi politik yang telah digunakan sebelumnya dalam komunitas.

Dalam hal ini partisipasi masyarakat sangat diperlukan untuk mewujudkan kota tanpak kumuh melalui program yang diadakan oleh pemerintah yaitu Program KOTAKU.

Adisasmita (2006) mengatakan bahwa partisipasi anggota masyarakat adalah keterlibatan anggota masyarakat dalam pembangunan, meliputi kegiatan dalam perencanaan dan pelaksanaan (implementasi) program/proyek pembangunan yang dikerjakan di dalam masyarakat lokal. Menangani fenomena pemukiman kumuh, dibutuhkan keterlibatan pemerintah dan masyarakat di dalamnya. Keterlibatan pemerintah disini sangat penting untuk mengatasi kawasan kumuh yang ada di kota. Pemerintah membuat program kegiatan secara terpadu antara pertumbuhan dan pemerataan, termasuk di dalamnya upaya peningkatan peran pemerintah yang lebih bisa menggerakkan partisipasi masyarakat. Harapannya agar dapat mengikutsertakan semua kelompok ataupun individu masyarakat agar mau berkomitmen untuk bekerja sama mulai dari tahap perencanaan sampai dengan tahap pengawasan program.

\section{METODE PENELITIAN}

Penelitian ini menggunakan metode kualitatif, yang mana penelitian ini berfokus hanya akan memberikan suatu gambaran mengenai fenomena-fenomena atau kejadian sosial yang terdapat 
atau terjadi didalam masyarakat, khususnya mengenai Partisipasi Masyarakat Kelurahan Kemboja dalam Program KOTAKU. Menurut Miles dan Hubermans dalam Sugiono (2008) Pengumpulan data dilakukan dengan teknik Wawancara,Observasi,dan Dokumentasi yang kemudian akan dianalisis dengan cara tiga alur kegiatan yang terjadi secara bersamaan yaitu reduksi data, penyajian data penarikan kesimpulan atau verifikasi.

\section{HASIL DAN PEMBAHASAN}

Partisipasi masyarakat dalam pembangunan sangat diperlukan dalam setiap tahapan pembangunan yang dimulai dari tahap perencanaan, tahap pelaksanaan, dan tahap evaluasi Ndraha,(2011). Partisipasi seseorang atau beberapa orang dalam Keterlibatan dapat berupa keterlibatan mental dan emosi serta fisik dalam menggunakan segala kemampuan yang dimilikinya sangat dibutuhkan dalam setiap pembangunan, untuk mewujudkan Kota Tanpa Kumuh partisipasi masyarakat sangat diperlukan untuk menjalankan program KOTAKU yang ada di Kelurahan kemboja.

\section{A. Partisipasi dalam Perencanaan}

Proses perencanaan program KOTAKU Kota Tanjungpinang khususnya Kelurahan Kemboja yang dilakukan oleh masyarakat dan penyelenggara tingkat kelurahan keikutsertaan masyarakat dan pengurus program dalam proses perencanaan pengembangan program KOTAKU yang ada di Kelurahan Kemboja. partisipasi masyarakat memiliki tingkatan yang dipengaruhi oleh seberapa besar pengaruh masyarakat dalam pengambilan keputusan. Nasdian, (2014) mengatakan Partisipasi masyarakat dalam perencanaan yang maksudnya adalah keikutsertaan masyarakat untuk menghadiri musyawarah atau rapat-rapat yang diadakan oleh Pemerintah Kelurahan beserta pemangku program lainnya dalam rangka melakukan suatu pembangunan infrastruktur di Kelurahan Kemboja.

Berdasarakan hasil olahan data dilapangan Dapat diketahui bahwa partisipasi masyarakat dalam tahap perencanaan masih tergantung situasi dan kondisi,apabila ada kesempatan waktu maka menghadiri musyawarah atau pertemuan yang diadakan oleh KOTAKU. Dan untuk pemberian ide atau saran masyarakat cenderung diam dan menerima saja apabila saran dan ide tersebut memberikan manfaat untuk wilayahnya maka masyarakat menyetujuinya.

Dan juga ditemukan berdasarkan hasil wawancara yang dilakukan dengan masyarakat ataupun pihak yang terlibat di dalam Program Kotaku untuk partisipasi dalam perencanaan yaitu dalam proses perencanaan atau partisipasi masyarakat nya terlihat sangat antusias sekali dengan adanya program KOTAKU ini,karena tujuan Program Kotaku ini kan meningkatkan akses terhadap infrastruktur dan pelayanan dasar di kawasan kumuh perkotaan untuk mendukung terwujudnya permukiman perkotaan yang layak huni, produktif dan berkelanjutan,program ini tidak hanya mengenai kebersihan atau buang sampah pada tempatnya tapi sangat banyak sekali. Selanjutnya yang menjadi permasalahannnya hanya sebagaian orang saja yang terlibat dala peroses tersebut, masih ada beberapa warga yang tidak tahu mengenai program tersebut sehingga ditaruh Plang-Plang serta rincian pekerjaan dengan tujuan agar muncul kesadaran masyarakat pentingnya program KOTAKU ini,dan dari pihak pengurus juga membuka peluang kepada masyarakat untuk menyalurkan aspirasinya, tetapi tidak seluruh warga menyampaikan karena keterbatasan waktu sehingga hanya perwakilan dari masyarakat untuk menyalurkan aspirasi serta ide dan gagasannya.

Dalam sebuah pembanguan kehadiran partisipasi yang menyeluruh dari berbagai elemen masyarakat dalam proses perencanaan sangat dibutuhkan karena dengan adanya partispasi tersebut masyarakat akan muncul rasa memiliki yang lebih besar karena mereka akan merasa menjadi bagian dari dalam program tersebut. Tentunya dengan adanya partispasi tersebut rasa untuk menjaga dan 
merawat hasil pembagnunan tersebut menjadi semakin besar karena masyarakat merasa menjadi bagian yang memberikan sumbangsi terhadapa proses perencanaan pembangunan tersebut.

Pengambilan keputusan merupakan salah satu partisipasi masyarakat dalam perencanaan yang maksudnya adalah keikutsertaan masyarakat untuk menghadiri musyawarah atau rapat - rapat yang diadakan oleh aparat kelurahan atau desa beserta pemangku program lainnya dalam rangka melakukan suatu pembangunan infrastruktur di Kelurahan Kemboja.Partisipasi dalam bentuk ini memberikan kesempatan kepada masyarakat dalam menyampaikan pendapatnya untuk menilai sesuatu rancangan program yang akan dilaksanakan serta menentukan hasil keputusan untuk dilanjutkan atau tidak.Dengan demikian agar dapat lebih menumbuhkan rasa tanggung jawab untuk ikut serta menentukan keberhasilan program, masyarakat juga diberikan kesempatan untuk menilai sesuatu keputusan atau kebijakan yang sedang berjalan. Partisipasi dalam pembuatan keputusan merupakan bentuk program yang disesuaikan dengan kepentingan masyarakat itu sendiri.

Untuk partisipasi pengambilan keputusan dalam program KOTAKU masyarakat juga dilibatkan serta masyarakat juga diberikan kesempatan untuk memberikan pendapat dan saran dalam pengambilan keputusan yang ditentukan dalam program KOTAKU. Dengan tujuan agar rencana yang diharapkan dan pengambilan keputusan sesuai dengan apa yang diinginkan oleh masyarakat, yang dianggap bisa bermanfaat dan dimanfaatkan secara bersama - sama.

Berdasarkan hasil data dilapangan dapat diketahui untuk partisipasi pengambilan keputusan dalam program KOTAKU masyarakat juga dilibatkan serta masyarakat juga diberikan kesempatan untuk memberikan pendapat dan saran dalam pengambilan keputusan yang ditentukan dalam program KOTAKU. Dengan tujuan agar rencana yang diharapkan dan pengambilan keputusan sesuai dengan apa yang diinginkan oleh masyarakat, yang dianggap bisa bermanfaat dan dimanfaatkan secara bersama-sama. Setelah Masyarakat diberi kesempatan untuk menyampaikan gagasan serta ide yang dimiliki sehingga dalam pertemuan tersebut ditemukan kesepakatan baru akan dilanjutkan ke tahap selanjutnya.

Namun yang sangat disangakan disini adalah partispasi dalam bentuk pengambilan keputusan kembali tidak semua masyarakat yang terlibat, bahakan dari hasi data di lapangan ada masyarakat yang tidak tau kapan ada pembahasan mengenai pembangunan infrastruktur dari KOTAKU, mereka tau ketikaa pembangaunan sudah dilaksanakan. Pelibatan partisipasi masyarakat tidak berjalan secara menyeluruh dalam setiap elemen masyarakat, hal ini sangat menghawatirkan bagi keberlanjutan dari hasil pembangunan tersebut dikemudian hari.

\section{B. Partisipasi dalam Pelaksanaan}

Partisipasi pelaksanaan yang dilakukan oleh masyarakat dan penyelenggara program tingkat kelurahan seperti masyarakat ikut serta dalam pelaksanaan program KOTAKU secara langsung. pada tahap ini maksudnya adalah pelibatan seseorang pada tahap pelaksanaan pekerjaan suatu proyek atau pembangunan. pada tahap ini maksudnya adalah pelibatan seseorang pada tahap pelaksanaan pekerjaan suatu proyek atau pembangunan. Keterlibatan masyarakat dalam pelaksanaan pembangunan sangatlah penting mengingat masyarakat yang nantinya akan menggunakan hasil pembangunan tersebut.

Untuk partisipasi dalam pelaksanaan program KOTAKU masih dikatakan kurang dikarenakan masih adanya pekerjaan lain yang lebih diutamakan oleh masyarakat yaitu mereka harus bekerja dalam pemenuhan kebutuhan sehari - hari yang memang tidak bisa ditinggalkan. Dan masih ada yang tidak ikut atau jarang mengikuti pelaksanaannya karena alasan adanya urusan lain tetapi 
masyarakat yang tidak terlibat juga ada yang ikut menyumbangkan konsumsi untuk warga lain yang ikut berpatisipasi sebagai pengganti keterlibatan mereka dalam tenaga.

Dari hasil wawancara yang dilakukan dengan masyarakat dan pihak terkait program KOTAKU mengenai partisipasi masyarakat secara fisik berbentuk Uang (Money) atau Konsumsi (consumption) yaitu masyarakat tidak ada dilibatkan dalam menyediakan sumbangan berbentuk dana atau uang itu sudah tersampaikan kepada Ketua RW dan RT setempat karena memang dari program KOTAKU sendiri sudah menyediakan anggaran yang memang khusus untuk melaksanakan program tersebut,dan jika ada masyarakat yang diminta uang itu sama saja dengan tindakan pungutan liar,tetapi jika dalam bentuk konsumsi masyarakat terlibat seperti menyediakan kue,kopi dan teh untuk masyarakat lain yang bekerja sebagai bentuk partisipasi nya untuk menciptakan solidaritas antar masyarakat dan apabila ada masyarakat yang tidak hadir juga bisa melibatkan diri dalam partisipasi menyediakan konsumsi sebagai bentuk partisipasinya walaupun tidak secara langsung.

Berdasarkan hasil wawancara yang dilakukan dengan masyarakat dan pihak terkait program KOTAKU dalam partisipasi untuk pelaksanaan masyarakat antusias sekali dalam program KOTAKU ini karena tujuan pembangunan untuk wilayahnya,tetapi ada juga masyarakat yang tidak bisa terlibat dalam pelaksanaan tidak semua hadir dikarena tuntutan pekerjaan yang tidak bisa ditinggal namu masyarakat lain juga ada yang berantusias dalam program ini. Partisipasi dalam pelaksanaan program KOTAKU masih dikatakan kurang dikarenakan masih adanya pekerjaan lain yang lebih diutamakan oleh masyarakat yaitu mereka harus bekerja dalam pemenuhan kebutuhan sehari - hari yang memang tidak bisa ditinggalkan.

Namun di sisi lain hasil lapangan juga menunjukan bahwa masih terdapat masyarakat yang tidak terlibat sama sekali dalam proses pembangunan, hal ini dikarenakan informan mengakui bahwa sosialisasi program tidak merata dan menyeluruh kesemua elemen masyarakat. Hal ini terjadi dalam partispsiasi massyrakat di keluarahan Kamboja Kota Tanjungpinang, harusnya program ini dapat menjangkau setiap elemen masyarakat sehingga seluruh masyarakat yang menjadi sasaran dari program benar-benar bisa merasakan kebermanfaatan bahakan mereka bisa menjadi mitra pemerintah dalam proses pembangunan dan perawatan dari manfaat program pembangunan.

\section{Partisipasi dalam Evaluasi}

Partisipasi masyarakat dalam menilai atau mengevaluasi pembangunan merupakan keterlibatan masyarakat dalam menilai sejauh mana pelaksanaan pembangunan sesuai dengan rencana dan sejauh mana hasilnya dapat memenuhi kebutuhan masyarakat. Dalam hasil penelitiannya Partisipasi ini bertujuan juga apakah pelaksanaan program KOTAKU telah sesuai dengan rencana yang ditetapkan, masyarakat juga memperoleh hasil dari program Kotaku yang telah dibuat, tahap ini merupakan tahapan penerimaan hasil dari apa yang telah direncanakan dan telah dilaksanakan dalam setiap proses pembangunan.

Berdasarkan hasil wawancara yang dilakukan mengenai partisipasi untuk evaluasi program KOTAKU yaitu ingin mewujudkan 0\% kawasan Kumuh dimana setelah adanya program KOTAKU ini mampu mengurangi angka kumuh yang sebelumnya terjadi masyarakat juga sangat terbantu dengan adanya program KOTAKU dimana masyarakat merasakan dampak yang lebih baik yaitu jembatan yang sebelumnya tidak layak menjadi layak serta masyarakat lebih paham dan sadar untuk menjaga lingkungan dengan adanya pemberdayaan yang diberikan program KOTAKU tersebut. Ini adalah merupakan tanggapan dari warga yang terlibat dalam proses perencanaan dan pelaksanaan. Namun dari hasil lapangan yang telah di peroleh ternyata juga terdapat fakta dari masyarakat yang tidak 
terlibat dalam setiap proses juga memberikan tanggapan bahwa mereka tentu saja akan menerima hasil yang telah dibangun selagi masih memberikan manfaat kepada masyarakat. Untuk kedepannya apakah nanti masyarakat akan mampu bersenergi didalam keberlanjutan program seperti merawat berbagai fasilitas yang telah dibangun tentu saja masih menjadi kekhawatiran.

Masyarakat yang heterogen baik dari segi pendidikan maupun identitas budayanya tentu saja akan memiliki cara pandang yang berbeda dalam memandang sebuah pembagunan. Jika masyarakat memiliki pendidikan dan pengetahuan yang tinggi maka tentu saja mereka akan dengan mudah untuk memahami dan memaknai sebuah tujuan dari pembangunan, namun sebaliknya jika kemampuan pendidikan mereka rendah tentu saja akan menjadi pekerjaan rumah besar yang harus dikerjakan oleh berbagai stekholder yang akan melaksanakan pembangunan. Perlu adanya pendekatan-pendekatan yang dapat langsung dijangkau oleh masyarakat deri berbagai latar belakang pendidikan.

Dalam mewujudkan peran serta masayrakat yang maksimal agar terwujudnya pembangunan yang berkelanjutan model bottom up adalah model yang paling tepat. Karena jika proses pembanguna dimulai dari mengintegrasikan setiap keinginan masyarakat tentu saja akan menimbulkan rasa senasib sepenanggungan akan hasil dari pembangunan. Memiliki rasa tanggung jawab bersama akan fasilitas yang telah dibangun untuk terus menjaga dan merawat agar manfaat dari fasilitas tersebut terus terjaga dengan baik.

\section{KESIMPULAN}

Berdasarkan hasil penelitian yang sudah dilakukan maka ditarik kesimpulan yaitu untuk bentuk partisipasi masyarakat terhadap program Kota Tanpa Kumuh (KOTAKU) di Kelurahan Kemboja masih terdapat masyarakat yang benar-benar berpartispasi dalam berbagi dimensi mulai dari perencanaan, pelaksanaan sampai dengan pada tahap evaluasi. Partisipasi dilakuakan sejak awal program ini mulai dijalankan diwilayah tempat tinggal mereka. Namun hasil temuan dilapangan juga menunjukan bahwa tidak semua elemen masyarakat ikut berpartispasi. Bahkan dari hasil temuan didalam lapangan ada masyarakat yang sama sekali tidak tahu adanya program KOTAKU, mereka hanya melihat bahwa adanya proses pembangnunan tentu dilakuakn oleh pemerintah tanpa mengetahui bahwa program tersebut adalah program yang ditujukan untuk mengurangi tingkat kumuh di wilayah tempat tinggal mereka. Dari hasil penelitian juga dapat dilihat bahawa pelaksana tugas telah berupaya untuk meningkatkan partisipasi dari masyarakat dalam pelaksanaan program, namun karena keterbatasan sumber daya manusia sehingga model sosialisasi yang harusnya bisa berlaku massif bagi seluruh elemn masyarakat tidak berjalan. Selain itu masih rendahnya tingkat kesadaran masarakat akan pentingnya partisipasi dan keterpaduan seluruh elemen masyarakat dalam proses pembangunan juga menjadi salah satu penghambat meningkatnya partisipasi masyarakat dalam pembangunan yang dilaksanakan pelaksana program KOTAKU.

\section{DAFTAR PUSTAKA}

Adisasmita, Rahardjo. 2006. Pembangunan Pedesaan dan Perkotaan. Yogyakarta: Graha Ilmu Chandra, Eka dkk. 2003. Membangun Forum Warga "Implementasi Partisipasi dan Penguatan Mayarakat Sipil". Yayasan AKATIGA. Bandung

Nasdian, F. T. (2014). Pengembangan masyarakat. Jakarta: Yayasan Pustaka Obor Indonesia.

Sinulingga, B.D. 2005. Pembangunan Kota. Tinjauan Regional dan Lokal. Jakarta: Pustaka Sinar Harapan. 
Soekanto, Soerjono.1993.Kamus Sosiologi, Jakarta: PT. Raja Grafindo Persada.

Sumaryadi, I Nyoman.2010.Perencanaan Pembangunan Daerah Otonom dan Pemberdayaan Masyarakat. Jakarta: Penerbit Citra Utama

Sugiyono. 2013. Metode Penelitian Pendidikan Pendekatan Kuantitatif, Kualitatif, dan R\&D. Bandung: Alfabeta.

Ndraha, Taliziduhu. 2011. Kybernology (Ilmu Pemerintahan Baru). Jakarta : Rineka Cipta.

Putri, R. A., Astuti, W., \& Rahayu, M. J. (2016). Community Capacity in Providing Neighborhood Unitscale Social Infrastructure in Supporting Surakarta Child Friendly. Procedia - Social and Behavioral Sciences, 227, 536-544. doi:10.1016/j.sbspro.2016.06.112 diakses tanggal 20 Januari 2020 